\title{
Building simply
}

It is a truth universally acknowledged that whenever practising architects are invited to address a conference theme they take it as an opportunity to present their recent work. And so, at a recent one-day symposium convened at the Welsh School of Architecture around the topic of 'Building Simply' (pp. 112-150), it is not altogether surprising that the only memorably 'simple' constructions on offer were the work of a landscape architect, Roland Raderschall. True, Raderschall's climber-clad steel frames (p. 112, illustrated in Gordon Murray's perspective piece) create impressive rooms - but they are required only to filter, not exclude the weather - while his elemental walls of turf, clay and tufa (pp.132-137) are designed to engage in an altogether more dynamic dialogue with the weather than Aldo Rossi had in mind when, in A Scientific Autobiography, he recalled seeing the fog enter Alberti's great church in Mantua and realised that 'architecture is made possible by the confrontation of a precise form with time and the elements'.

The search for 'precise form' in architecture can have many grounds, but the extent to which it can be founded in the manifest 'truths' of construction - one of the implications of that perennial icon of simple building, the primitive hut - will always remain a lively, and frequently timely, subject for historical and theoretical debate. Yet rarely can this abiding aspiration have been as problematic as it has become now, when ever more stringent performance requirements, combined with the economic advantages of assembling rather than building buildings, make the direct expression of constructional means highly problematic.

As an ideal, 'building simply' retains a potent appeal for many, all the more so as the possibility of achieving it in most areas of practice disappears over the horizon. The key, as ever, is not in a naïve Expressionist devotion to selective constructional facts, as attempted in British High Tech, but in the convincing representation of satisfying constructional form: architects aspiring to build simply might do well to recall Adrian Stokes's observation apropos the classical ballet, that 'every move, however difficult, must be performed with the appearance of ease'.

Appearances, in the art of architecture, are the proverbial lies we use to tell the truth - a truism that emerges as one of the conclusions of Jess Hrivnak's exploration of the complexities and contradictions of a would-be model of sustainable building, Hopkins Architects' 'Inn the Park' restaurant (pp. 167-176). As consumers of around half the world's energy, buildings clearly have to be a major part of the solution to our global environmental challenges, and while it would be naïve to suggest that 'building simply' offers a straightforward solution to these complex problems, as both an ethic and aesthetic - to borrow Reyner Banham's assessment of another would-be call to order, the New Brutalism it represents a more promising line of enquiry than the neo-baroque excesses of our consumer culture. 


\section{architectural research quarterly}

\section{Subscribe now for 2008}

Innovative in conception, unique in breadth and generously illustrated, this pace-setting quarterly publication from Cambridge University Press links, on a global scale, the worlds of architectural practice and research. arq regularly includes extensive peer-reviewed sections on design, history, theory, construction, environmental design, information technology and practice - as well as structures, urbanism and documents. These are supplemented by letters, reports, reviews, a directory of specialist research centers and consultancies and an annual index. Each issue opens with a leader and closes with insight, a personal end-piece. In its ten year history, arq has published work from all over the world: from Chile to Sweden and from Japan to the Netherlands - with a strong representation from the United Kingdom and United States. arq, like architecture itself, is all-embracing and written by and for both practitioners and academics. It provides an outlet for all those who wish to disseminate their work to an international audience.
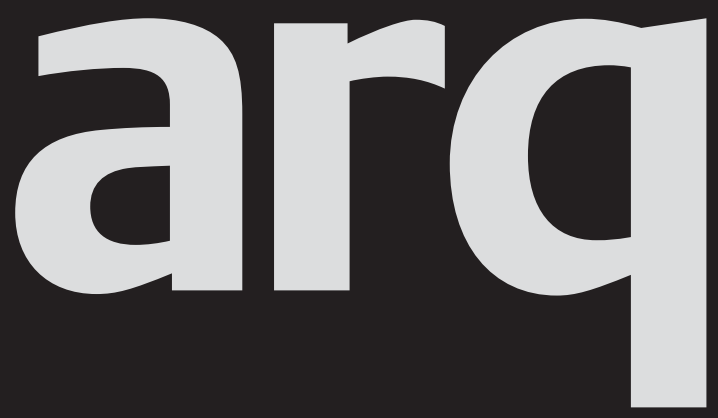

Please enter my subscription to arq: architectural research quarterly, volume 11, 2007 $\square £ 156 / \$ 252$ institutions print and electronic $\square £_{30} / \$ 50$ students print only

$\square$ £42/\$64 individuals print only

EU residents only. VAT may be payable at your local rate if not registered.

Our VAT registration number: GB 214141614 If registered, your VAT registration no:

Total subscription payment $£ / \$$ EU residents only, if not registered add VAT at appropriate rate

Canadian residents, add 7\% GST \$

Total $\mathbf{E} / \$$

Name

Address

Payment enclosed

Cheque in sterling or US dollars

(payable to Cambridge University Press)

Credit Card - VISA | MasterCard | American Express (delete where applicable)

Card no

Expiry date

Signature

Photocopy this page and send your order to:

Journals Customer Services, Cambridge University Press, The Edinburgh Building, Cambridge, CB2 8RU, UK

T $+44(0) 1223326070$

$\mathrm{F}+44(0) 1223315052$

E journals@cambridge.org

or in USA, Canada and Mexico send to:

Cambridge University Press, 32 Avenue of the

Americas, New York NY 10013-2473, USA

T (914) 9379600

F (914) 9374712

E journals_subscriptions@cup.org 